\title{
Conservation of geosites as a tool to protect geoheritage: the inventory of Ceará Central Domain, Borborema Province - NE/Brazil
}

\author{
PÂMELLA MOURA ${ }^{1,2}$, MARIA DA GLÓRIA M. GARCIA ${ }^{1,2}$, JOSÉ B. BRILHA ${ }^{3}$ and WAGNER S. AMARAL ${ }^{1,4}$ \\ ${ }^{1}$ Programa de Pós-Graduação em Geologia, Departamento de Geologia, Universidade Federal \\ do Ceará, Campus do Pici, Bloco 912/913, 60440-554 Fortaleza, CE, Brazil \\ ${ }^{2}$ Núcleo de Apoio à Pesquisa em Patrimônio Geológico e Geoturismo (GeoHereditas), Instituto de Geociências, \\ Universidade de São Paulo, Rua do Lago, 562, Cidade Universitária, 05508-080 São Paulo, SP, Brazil \\ ${ }^{3}$ Departamento de Ciências da Terra, Universidade do Minho, Campus de Gualtar, 4710-057, Braga, Portugal \\ ${ }^{4}$ Instituto de Geociências, Universidade Estadual de Campinas, Rua Carlos Gomes, \\ 250, Cidade Universitária, 13083-870 Campinas, SP, Brazil
}

Manuscript received on August 2, 2017; accepted for publication on October 3, 2017

\begin{abstract}
The Ceará Central Domain, in the northern Borborema Province/NE Brazil, encompasses important geological records (geosites) which allow understanding a relevant period of the Earth's evolution, mainly associated to Neoproterozoic Brazilian/Pan-African Cycle and West Gondwana amalgamation, besides Neoarchean to Ordovician records. The presented geoheritage inventory aims to characterise the geosites with scientific relevance of Ceará Central Domain. By applying a method for large areas, the final selection resulted in eight geological frameworks represented by 52 geosites documented in a single database. This is the first step for a geoconservation strategy based on systematic inventories, statutory protection, geoethical behaviour and awareness about scientific, educational and/or cultural relevance of geosites.
\end{abstract}

Key words: geological heritage, geoconservation, inventory, Borborema Province, Brazil.

\section{INTRODUCTION}

Since the establishment of the first concepts of Geology, the development of Earth Sciences depends on the characterisation and interpretation of geodiversity. In spite of all technological advances of the last decades, a significant part of geological research still depends on observation and study of outcrops. Nevertheless, many outcrops used for scientific and educational purposes were destroyed or modified by human intervention, mainly due

Correspondence to: Pâmella Moura

E-mail: pamella_mm@yahoo.com.br to the growing demand for natural resources and disorderly occupation both in urban and rural areas.

Nature conservation has been a recurrent and valued scientific subject at least since the 1970s, despite predominantly applied to biodiversity conservation. Although some countries have been carrying out geological conservation practices at least since the beginning of the 20th century, like the United Kingdom, Spain and the USA (Carcavilla et al. 2009, Thomas and Warren 2008), it has been often restricted to sites with great scenic beauty and potentially tourism elements, or associated with high-relevant areas in terms of 
biodiversity or archaeological values, some of them inscribed in the UNESCO's World Heritage list. It was only after the 1990s that geoconservation acquired global scale importance, especially after the First International Symposium for Geological Heritage Conservation (Digne-les-Bains, France, 1991) and the creation of the European Association for the Conservation of the Geological Heritage (ProGEO), in 1992.

In this context, geoconservation emerges as a new area within Earth Sciences in which the knowledge produced may be used to prevent, correct and minimize environmental impacts that cause risk for geoheritage, like inappropriate land use planning (Carcavilla 2012, Henriques et al. 2011). As pointed out by Borba et al. (2013), geoconservation aims the interaction between geoscientists with social issues such as environmental protection, sustainable development, education, and territorial planning. In this sense, geoconservation is a valuable tool on public policies.

In order to promote the inventory and conservation of the most representative geosites in terms of geological events, processes and features both on the national and international scale, in 1995 the International Union Geological Science (IUGS) created the GEOSITES Project (Wimbledon 1996). This project was an evolution of the former Global Indicative List of Geological Sites (GILGES), associated to the Global Database of Geological Sites of IUGS, which aimed a systematic selection of geosites based on specific geological frameworks, enabling their comparison in several scales (Wimbledon et al. 1999). According to Wimbledon (1996), the GEOSITES Project assumed that development of geosciences depends on complete access to a broad assortment of outcrops, both for scientific research and teaching. Despite this project had been closed by IUGS in the 2000s, its great importance was to encourage conservation of scientific relevant geosites, even if they do not constitute scenic or tourist attractions.
In this scenario, the Brazilian Commission for Geological and Palaeobiological Sites (SIGEP) was created in 1997 in response to a request from IUGS to propose new sites for feeding the GEOSITES database. The Brazilian Geological Survey's (CPRM) Geoparks Project was created in 2006 and also reflects the response of the Brazilian geological community to a worldwide demand. In this sense, the Araripe UNESCO Global Geopark is the most symbolic example of this process in Brazil, holding mechanisms to protect high scientific value sites, such as Pedra Cariri Geosite, one of the worlds' most important Cretaceous fossil sites. As an attempt to unify information on Brazilian geosites, CPRM also developed the GEOSSIT Platform as an assistance tool to register the inventory and quantitative evaluation at the national scale (Rocha et al. 2016, Schobbenhaus et al. 2015).

\section{FOUNDATIONS FOR GEOCONSERVATION}

One of the main targets on geoconservation is to define which geologically important sites should be conserved. How to select, among many possibilities, the most representative sites in terms of the geological history of a certain area? The way to solve this issue is to promote geosites selection by means of inventory (Brilha 2016, Henriques et al. 2011). Therefore, inventories must have welldefined objectives and methods and also evaluate geosites according to both specific scales and geological frameworks (Carcavilla et al. 2009, Lima et al. 2010, Wimbledon 1996). In this perspective, the geological heritage represents the group of geosites and/or other geodiversity elements systematically selected in such inventories.

Giving their decisive role for the selection of sites that will have priority on geoconservation policies, there are many inventory methods. Among these, the one from Brilha (2016) allows a separation between sites that are scientifically important (geosites) from those whose geodiversity 
elements are associated with other features, like great scenic beauty, recreational or educational values etc. (geodiversity sites). According to the method, potential geosites are compared within the same geological framework, allowing selection of the most representative in each category. Protection and conservation actions could be thus prioritised, especially when there is a lack of financial or other resources. In this way, while geosites reflect the scientific relevance of geoheritage, geodiversity sites may be valuable tools in the popularisation of science, teaching, and geotourism.

Another fundamental issue for geoconservation is the existence of laws guaranteeing the protection of geosites. In Brazil, there is a legal framework only focusing on protect specific occurrences, as speleological or paleontological heritage. For the other cases, this matter has been solved by adjustment of both environmental and cultural heritage laws. Mansur (2010b) suggests the wide use of the Brazilian National System for Conservation Units - SNUC (Brazil Federal Law 9.985/2000) and law for the protection of Brazilian National Historic and Artistic Heritage (Brazil Federal Decree 25/1937) for the conservation of geosites. Recently, Lima et al. (2016) reiterate the application of SNUC, as well as the Brazilian Forest Code (Brazil Federal Law 12.651/2012). These authors propose the use of both Permanent Protection Areas and Legal Reserve on rural properties modalities as tools for geoconservation.

However, without accompanied by strong recognition and belonging sense by local communities, legal protection laws are insufficient to assure geosites conservation. Lack of awareness among the population about the necessity to protect geoheritage can be the major obstacle to its conservation (Mansur 2010b). Moreover, geosites conservation by the geoscience community is another side of the same issue. Many outcrops are damaged when serving to scientific purpose, either by indiscriminate or destructive sampling methods, especially drill coring (Butler 2015, Druget et al. 2013).

This scenario is a problem worldwide and even more serious in countries where part of geosciences community has not yet recognised the importance of geoheritage conservation. In Brazil, for example, Earth Sciences students are encouraged to indiscriminate hammering and field sampling, even without a clear scientific/ educational purpose, so endangering the quality and the integrity of outcrops. This behaviour clearly indicates a gap between theory and practice on geological heritage conservation. Thus, application of geoethical educational principles can reduce possible damages due to scientific and educational uses and also guide the geosciences community on the execution of its activities (Druget et al. 2013, Mansur et al. 2017). Geoethics represents an opportunity for geoscientists to become more conscious of their social role and responsibilities in conducting their activities (IAPG 2012). In Europe, where geoconservation is better established, rock sampling by undergraduate students during fieldworks and didactic practices are usually not allowed by universities, and even for research, a prior license can be required. The Geological Fieldwork Code and the Code of Conduct for Rock Coring developed by the Geologists' Association of the United Kingdom are in consonance with this ethical proposal, introducing good practices in field works and rock sampling. Thus, geoconservation and geoethical behaviour need to be together in order to achieve geoheritage protection.

As a first and crucial stage in any geoconservation action, the inventory presented here aims to characterise the geoheritage occurring in the central-northern portion of the Ceará Central Domain (CCD), and also to use the geosites for reconstructing its geological history. The CCD is one of the tectonic domains of Borborema Province presenting relevant geological records associated with Paleo- to Neoproterozoic orogenic 
events, mainly the Brasiliano-Pan African Cycle (Brito Neves et al. 1999). Arid climatic conditions favoured the exposition and preservation of relevant outcrops to the geosciences, whether for research or teaching. Beyond the clear scientific relevance concerning recognition and protection, this inventory intends to propose geosites that can contribute to a future and systematic inventory of geological heritage in Brazil.

\section{GEOLOGICAL SETTING}

The CCD is the most expressive geotectonic unit of the Northern Borborema Province and occupies most of the Ceará State (Figure 1). It is limited by the Senador Pompeu Shear Zone, to the southeast, and the Transbrasiliano Lineament (locally SobralPedro II Shear Zone), to the northwest.

According to Fetter et al. (2000) the CCD may be divided into four major litho-structural units: (I) Archean Nuclei (Tróia Massif) composed of remnants of tonalite-trondhjemitegranodiorite (TTG) sequences, Paleoproterozoic mafic/ultramafic complexes and metavolcanicsedimentary sequences (Brito Neves et al. 1999, Costa et al. 2015); (II) Paleoproterozoic juvenile gneissic basement composed of both para- and orthogneisses, migmatites, and medium-to-high grade metamafic rocks (Arthaud et al. 2008, Fetter et al. 2000); (III) Neoproterozoic volcanosedimentary supracrustal sequences characterised by metapelites and metapsamites, mainly kyanitemuscovite-biotite gneisses, sillimanite-garnet gneisses, quartzites, amphibolites, marbles, granulites and retroeclogites (Amaral et al. 2012, Santos et al. 2015); and (IV) the Santa Quitéria magmatic arc, mainly composed of Neoproterozoic plutonic rocks with magmatic arc isotopic signatures (Fetter et al. 2003). These lithostructural units were strongly affected by strike-slip shear zones, at the end of Neoproterozoic, creating expressive records on lithology and designing the present geometric configuration of the terranes. Later, mainly during the Cretaceous, the inherited structures controlled dissection processes and induced a strong NE-SW alignment of the residual massifs (Peulvast and Sales 2002, Sales and Peulvast 2007). As a result, the present landscape is characterised by large peripheral depressions crosscutted by both residual massifs and crystalline inselbergs (Lima et al. 2000). The CCD also hosts various economic deposits such as iron, manganese, copper, gold, and uranium (e.g. Parente et al. 2015, Veríssimo et al. 2016).

\section{MATERIALS AND METHODS}

The choice of CCD as the focus of this work is based on the definition of terrane following Irwin (1972) and Kearey and Vine (1998). As stated by these authors, a terrane (domain) is "a tectonic-stratigraphy unit that comprises a set of lithotypes individualised by faults or shear zones and characterised by an association of geological features, mainly regarding geodynamic evolutionary processes, which differentiates it from the adjacent terrane". In this sense, although holding lithotypes of different ages, compositions and geodynamic scenarios, the domain shares a common geological history that would be essential for a good definition of frameworks. In the present study, our area was delimited in centre-north portion of CCD due to the large size of this domain.

Following Brilha's (2016) inventory method and Wimbledon's et al. (1999) framework approach, the development of this inventory can be summarised in four essential steps: a) definition of geological frameworks; b) identification of potential geosites; c) field evaluation of geosites and d) selection and characterisation of geosites.

\section{DEFINITION OF GEOLOGICAL FRAMEWORKS}

A geological framework is a frequently used tool in national inventories to systematise the geological 


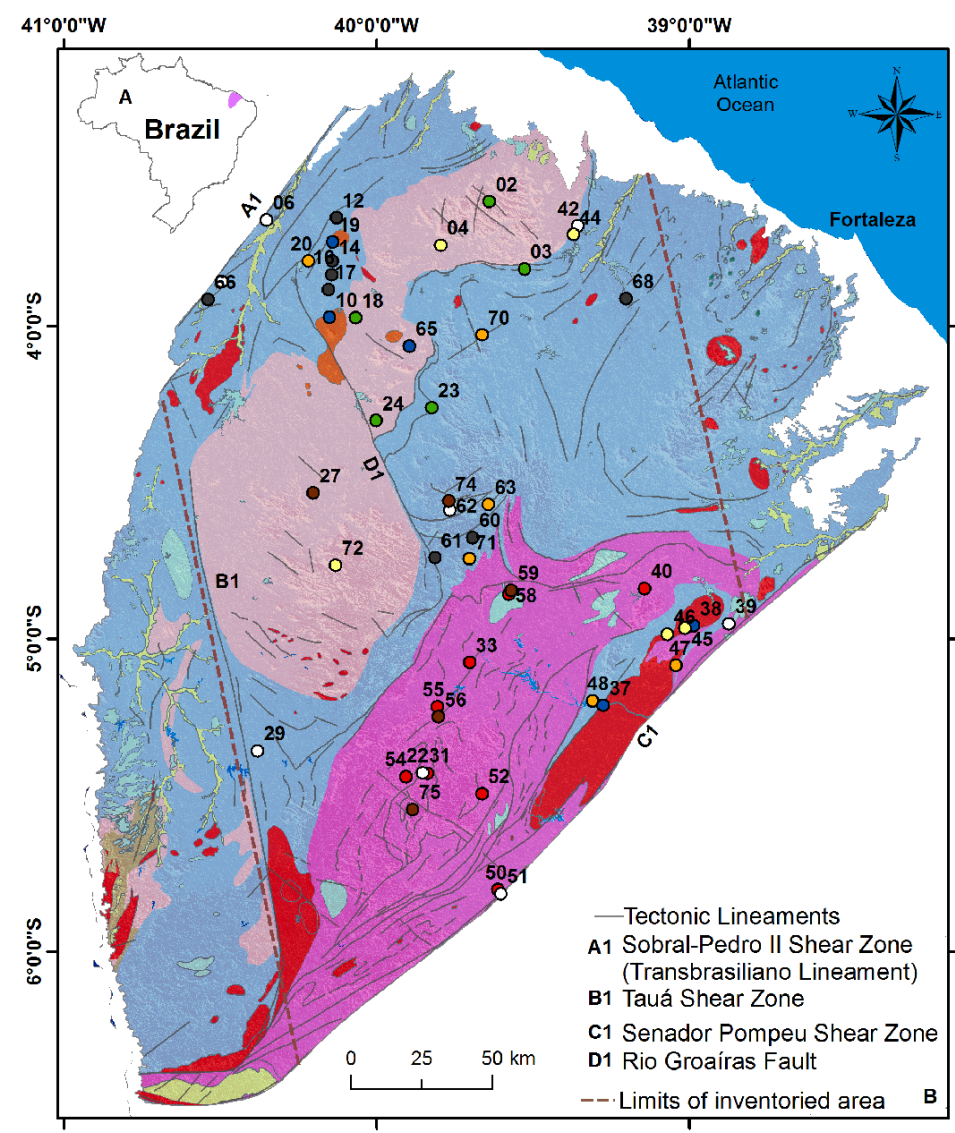

Geological Frameworks / Geosites

Geomorphological Units

- Granitic Rocks

- Shear Zones

- Mineralization

- Santa Quitéria Magmatic Arc

- Granulites and Retroeclogites

- Supracrustal Sequences

- Archaean and Palaeoproterozoic Terranes Simplified Geology

Undifferentiated Sedimentary Cover

- Messejana Magmatism

- Intrusive Palaeozoic Units (Cambrian/Ordovician)

- Neoproterozoic Intrusive Units

Tamboril Santa Quitéria Intrusive Suite

- Ceará Complex (Palaeo- and Neoproterozoic Units)

- Novo Oriente Group

- Cruzeta Complex and other Palaeoproterozoic Units

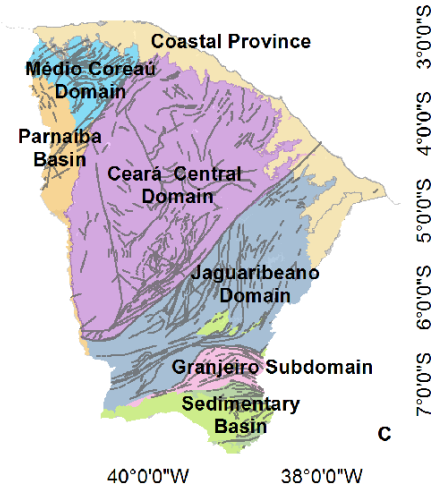

Figure 1 - a) Located of study area; b) Simplified geology of CCD and geosites (indicated by number). Red dashed lines show the limits of the inventoried area. c) Northern block of Borborema Province in the Ceará State (modified from Cavalcante et al. 2003).

knowledge of a certain area in terms of the main geological and geomorphological events, in order to ensure the representativeness of geodiversity (Brilha et al. 2005, Wimbledon 1996). In the present inventory, the definition of geological frameworks was made based on tectonic-stratigraphy units described in the Geological Map of Ceará State (Cavalcante et al. 2003), literature reviewing and experts suggestions. The main characteristics, that should be represented by potential geosites, were defined for each framework.

\section{IDENTIFICATION OF POTENTIAL GEOSITES}

Once geological frameworks were defined, the selection of potential geosites was carried out through intense literature reviewing and suggestions from experts researching or teaching in the CCD region. These collaborators include essentially members of the Department of Geology at the Federal University of Ceará (UFC) and at the University of Campinas (UNICAMP).

A list with 83 potential geosites was created by means of a worksheet containing basic information such as outcrop descriptions, geological units, justification of scientific value (including information on the available geochronological and geochemical data), rarity, scientific knowledge and literature references, and location with geographical coordinates obtained by GPS, among other relevant documents,. As a general rule, the potential geosite list was composed of $i$ ) 
Outcrops either studied or mentioned in scientific publications and technical reports, like the ones produced by the Geological Survey of Brazil (CPRM) and; ii) Outcrops frequently visited during field classes of geology courses or included in geological field guides in scientific events. However, some geosites were selected due to their notable geological or geomorphological features, recognised by specialists but without relevant scientific publications yet.

\section{FIELD EVALUATION OF GEOSITES}

Field activities were carried out during 2015 and 2016 and included a description of the main geological features of the potential geosites, correlation of each site to a specific geological framework, and comparison of preliminary information to the current state of the outcrops. During fieldwork, some potential geosites were not found due to missed information on the location, coordinates, description or because they had been destroyed by natural or human activities.

Each potential geosite was assessed taking into account its integrity, fragility, and vulnerability (natural and anthropogenic threats - such as weathering, landslides, mining, and irregular urban occupation). Detailed photo-documentation, cultural and ecological aspects and rigorous description of locations and access conditions were also performed.

\section{SELECTION AND CHARACTERISATION OF GEOSITES}

Geosites that constitute the final inventory list are the most representative of each geological framework and were selected based on the data obtained during fieldwork. When two or more geosites had the same geological features, sites with the highest number of scientific publications or with the highest integrity conditions were prioritised. However, sites with high rarity in the study area, even with low integrity, were selected to the final list.

Each geosite was classified according to its primary geological interest, as well as new interests identified in the present work. These interests represent the major geological characteristic of the geosite, for example: paleontological, geomorphological or igneous. They were also classified according to the size category (FuertesGutiérrez and Fernández-Martínez 2010): area (>1 ha with just one type of interest), complex area (large areas with several interests), point ( $<1$ ha with just one geological feature), section $(<1$ ha with features having a linear spatial development) and viewpoints (an area of geological interest and its better observatory spot). The geosites were also evaluated regarding Brazilian legal framework: a) Brazilian Law for National Historic and Artistic Heritage Protection (Federal Decree-Law no. 25/1937); b) Brazilian System for Conservation Units - SNUC (Federal Law no. 9.985/2000); c) Brazilian Law for Natural Underground Cavities Protection (Brazil Decree-Law no. 99.556/1990 and 6.640/2008); d) Brazilian Forest Code (Federal Law no. 12.651/2012); and e) other specific laws, when applicable.

\section{RESULTS}

This inventory resulted in eight geological frameworks (Table I) represented by 52 geosites (Table II and Figure 2). Each geological framework is described and illustrated according to the most relevant characteristics and scientific value, main references and number of selected geosites. Despite the reasonable number of geological literature, some areas still lack more detailed research, especially in the north-east and south-east parts of the CCD. In these areas, it was difficult to find references and suggestions for potential geosites.

Eight main geological interests were identified: geochronological,geodynamics, geomorphological, 


\section{TABLE I}

Geological frameworks with justification for scientific value, number of geosites and tectonic-stratigraphy units.

Justification for Scientific Value
Litho-stratigraphy units

(Cavalcante et al. 2003)
Geomorphological Units (Figure 2)

Represent the CCD landscape, composed of relief elements resulting from differential erosion acting on crystalline rock terranes characterised by spatial predominance of peripheral depression crosscut by both residual massifs and inselbergs. Its evolution is related to the uplift of South American continental platform in response to opening and subsidence forces, which preceded the Atlantic Ocean rifting and marginal isostatic compensation in the Cretaceous (Maia et al. 2010, Peulvast and Sales 2002, Sales and Peulvast 2007). Two factors were preponderant to shape these landforms: the Neoproterozoic structural control and the climate variability (backwearing and etching process). Selected geosites aim to represent the most relevant features of CCD relief, especially by means view points that allow the observation of the landscape.

\section{Granitic Rocks (Figure 2)}

Comprises a diverse granitic assemblage (granodiorites, sienites, sienogranites, monzonites to monzogranites and granites) associated to the Brasiliano-Pan African Cycle, represented by stocks with diameters of a few dozens of metres to ring complexes and large batholiths covering up to $1000 \mathrm{~km}^{2}$, like the Quixeramobim Batholith. These granitoids present ages between ca. 590 and $470 \mathrm{Ma}$, being Ediacaran the period of major granitic generation in CCD despite has remained active during the Middle Ordovician (Almeida et al. 1999, Castro et al. 2012). High-K calc-alkaline composition and K-feldspar phenocrysts (larger than 10 $\mathrm{cm})$ are remarkable features in these rocks. Selected geosites aim to represent the diversity of these rocks and illustrate differences in terms of composition, texture, structure and ages.

\section{Shear Zones (Figure 2)}

This framework encompasses records of intense Neoproterozoic tectonism easily identified in all CCD, being characterised by two types of structures: 1) NE-SWoriented, preferably dextral, strike slip ductile shear zones, representing significant part of a huge continental shear zone system resulting from continental collision during the Brasiliano-Pan African Cycle (Arthaud et al. 2008); 2) Low-angle, napperelated structures resulting from regional compressive tectonics that culminated with thrusting of Ceará Complex supracrustal sequences over Cruzeta Complex lithotypes. Records of both structures occur extensively along the CCD. For these selection just representative outcrops of regional shear zones were considered, either for delimiting CCD or for being essential to understand geological processes present in other geosites.

\section{Mineralization (Figure 2)}

Thermo-tectonic events that outlined CCD geological framework support a diversified number of mineralization types, some of them holding high economic and strategic values. In general, these features resulted from either metamorphism of magmatic rocks or metal-bearing sediments, as well as a hydrothermal metasomatic processes related to the Brasiliano-Pan African Cycle. The main record range from Paleoproterozoic PGE-bearing chromitite and BIFs to Neoproterozoic skarns and phosphate-uranium deposits. Selected geosites aims to represent the main CCD mineralization types, mainly regarding their relationship with the geological evolution and economic relevance.
Number of selected geosites: 5

\section{Number of selected geosites: 5}

Itaporanga Intrusive Calc-alkaline Suite, Meruoca Intrusive Sub-alkaline to Alkaline Suite, Undifferentiated Granitoids

\section{Number of selected geosites: 9}

Transbrasiliano Lineament (Sobral-Pedro II Shear Zone) and Shear Zones: Senador Pompeu, Quixeramobim, Sabonete-Inharé, Umirim and Tauá

Number of selected geosites: 5

Complex Cruzeta and Complex Ceará 
TABLE I (continuation)

Justification for Scientific Value
Litho-stratigraphy units

(Cavalcante et al. 2003)

Number of selected geosites: 9

High-grade granulite and retrograded eclogite relics have been found in rocks that surround the Tamboril-Santa Quiteria Intrusive Suite. This discovery has been preponderant to understand the geological evolution of the region, especially regarding oceanic subduction processes associated to nappe stacking in the supracrustal sequences during the Brasiliano-Pan-African Cycle. The retroeclogites occurs as garnet-clinopyroxene amphibolite boudins and its main diagnostic features include thin plagioclase coronas around garnet and clinopyroxene and Na-plagioclase symplectites as pseudomorphs of omphacite. Granulite bodies occur usually both as clinopyroxene-garnet amphibolites or enderbites, with pressure and temperature records above $9 \mathrm{kbar}$ e $870^{\circ} \mathrm{C}$, respectively (Amaral et al. 2012, 2015, Ancelmi et al. 2015, Santos et al. 2009, 2015). Its selected geosites aim essentially, their rarity and fragility.

\section{Santa Quitéria Magmatic Arc (SQMA) (Figure 3)}

Comprehends rocks generated during the major magmatic event in the $\mathrm{CCD}$, which is intrinsically connected to Brasiliano-Pan African Cycle and West Gondwana collage. Comprises about $40 \mathrm{~km}^{2}$ from tonalite to granite anatetic-igneous rocks association brought about by numerous magmatic pulses and recognized as magmatic-arc products. Its evolution occurred between ca. 880 and $600 \mathrm{Ma}$ (Araújo et al. 2012, 2014, Fetter et al. 2003). Selected geosites represent the distinct magmatism phases; taking into account geochronological databases available.

\section{Supracrustal Sequences (Figure 3)}

These sequences surround the Tamboril-Santa Quitéria Intrusive Suite and comprise various associations of Paleo- to Neoproterozoic terrigenous metasedimentary rocks, mainly metapelites and metapsamites, whose depositional processes are related to the breakup of Rodinia, followed by a development of a magmatic arc (Arthaud et al. 2008). These rocks record low-angle thrusting under medium to high-grade metamorphism during the Brasiliano-Pan African Cycle, resulting in a complex nappe system associated to local shear zones, migmatisation and igneous intrusions (Arthaud et al. 2008). Selected geosites seek to represent the most characteristic lithotypes of each unit of the Ceará Complex.

\section{Archean and Paleoproterozoic Terranes (Figure 3)}

Represents the CCD basement, composed of Archean gneiss TTG nuclei (Tróia Massif), as well as Paleoproterozoic metavolcano-sedimentary greenstone sequences and mafic/metamafic complexes (Cruzeta Complex) and related to Rodínia paleocontinent (Brito Neves et al. 1999, Fetter et al. 2000). It has been subject of many researches particularly by its mining potential and geochronological features, and represents the oldest lithological group from CCD and one of the oldest from Northeastern Brazil. Its geosites aimed the most representative lithotypes of each lithostratigraphic unit on the basis on the geochronological database available.
Ceará Complex

(Canindé and Independência Units)

Number of selected geosites: 5

Tamboril-Santa Quitéria Intrusive Suíte

Number of selected geosites: 6

\author{
Ceará Complex \\ (Canindé, Independência and \\ Quixeramobim Unit)
}

Number of selected geosites: 8

Pedra Branca Unit, Mombaça Unit, Cruzeta Complex and its sub-units, Algodões Unit, Choró Unit, and Madalena Suite 


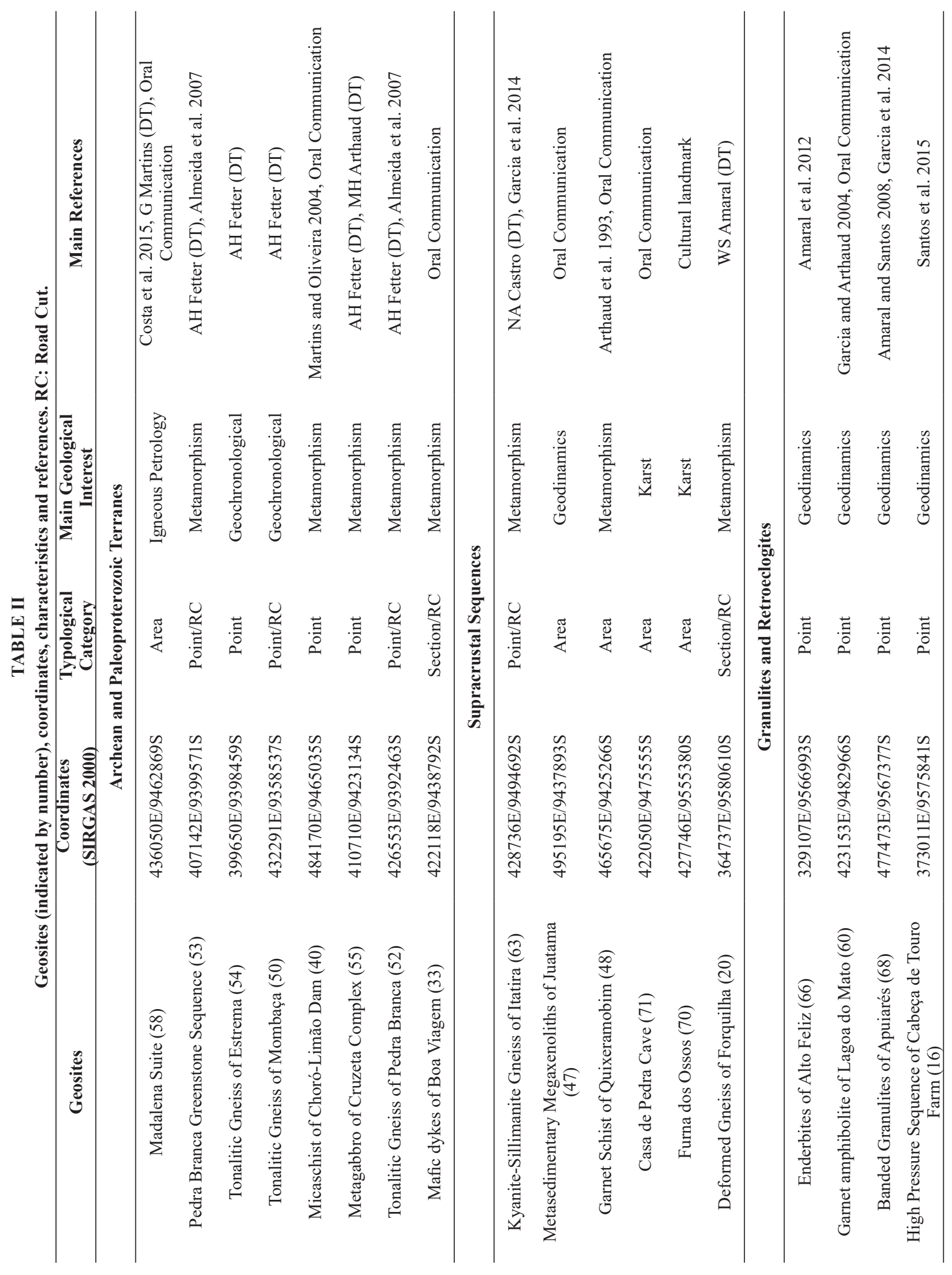




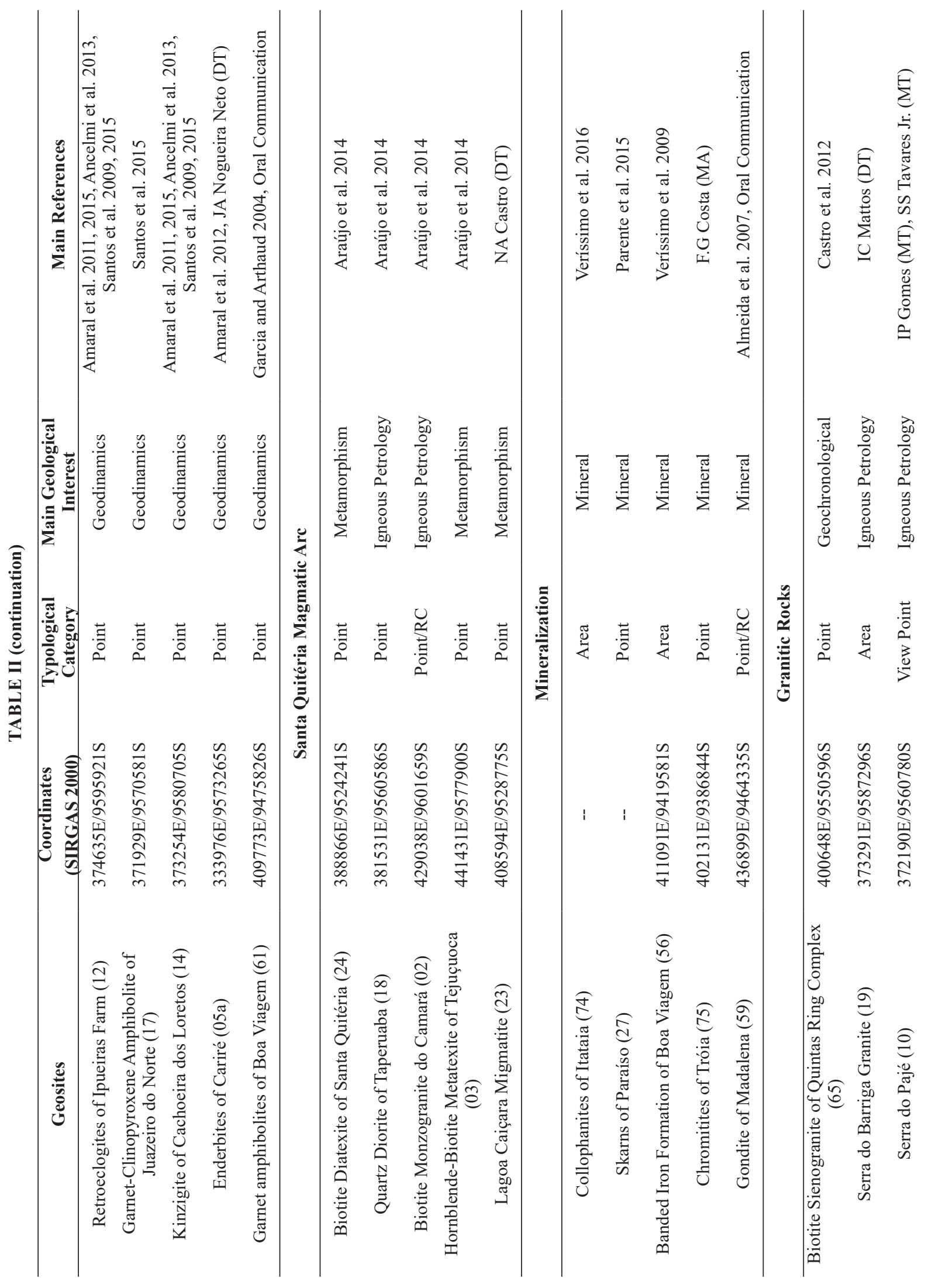




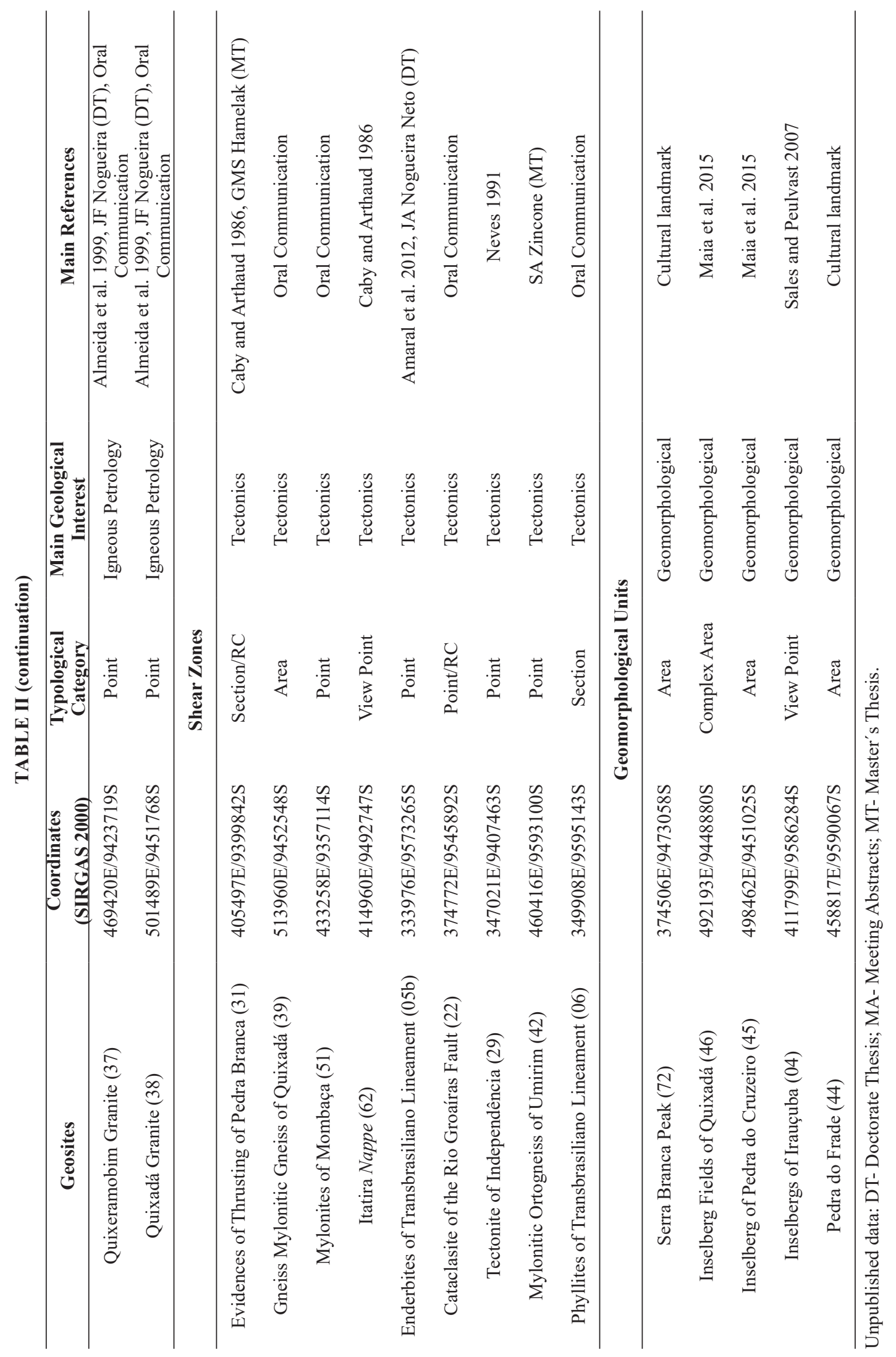



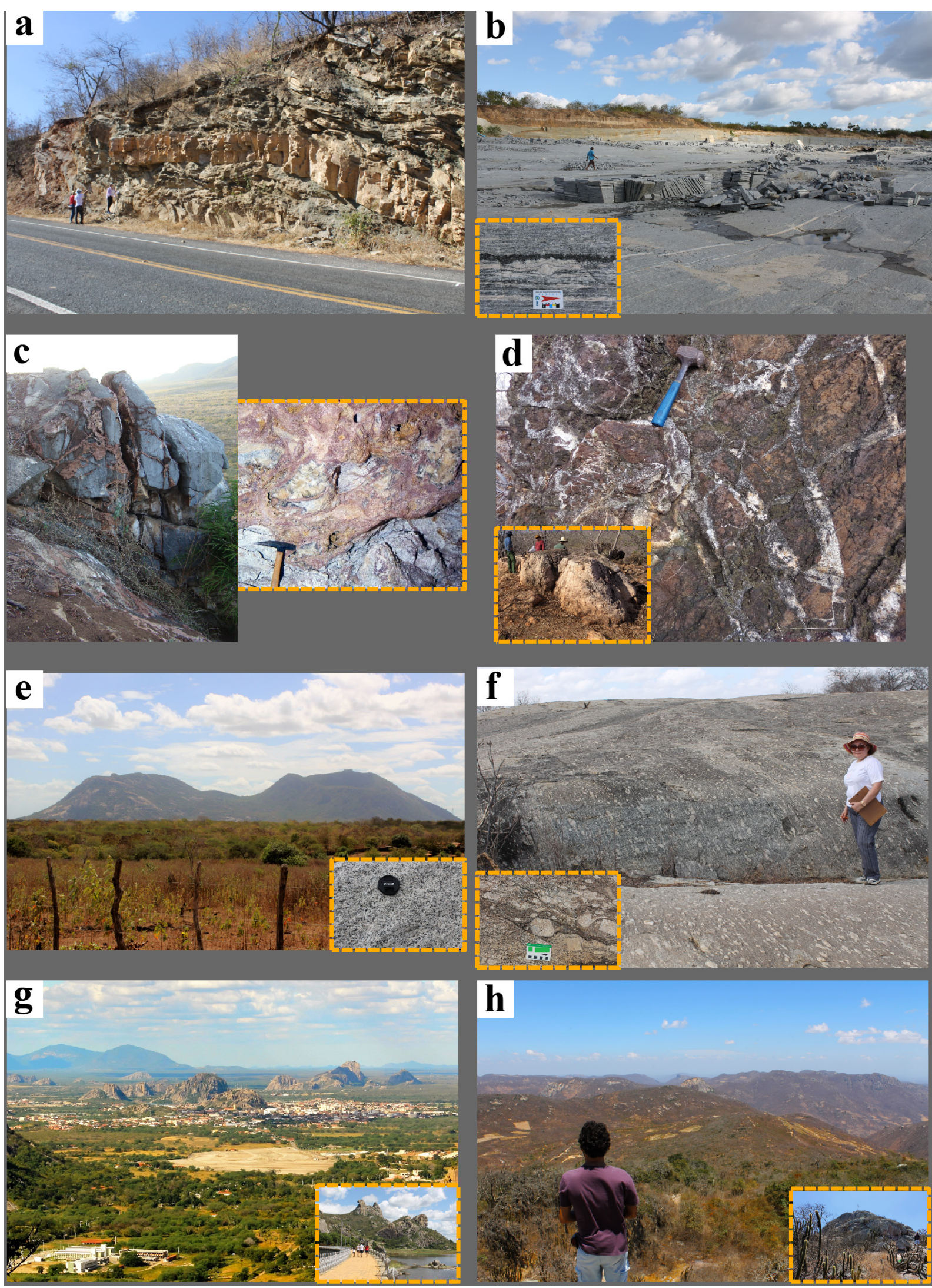
Figure 2 - Selected geosites of the geological framework "Shear Zones": a) Geosite Evidences of Thrusting of Pedra Branca: The best exposure of a low angle tectonics on Archean/Paleoproterozoic basement. Represent characteristic rock association of Pedra Branca Unit with interlayer between orthogneisses, often affected by boudinage amphibolites and mafic schist. The orthogneisses shows NNE-SSW low angle foliation, SSE mineral lineation and top-to NNW movement. b) Geosite Mylonitic Gneiss of Quixadá: This excellent outcrop is located within a quarry and constitutes records of dextral strike slip ductile Senador Pompeu shear zone. The geosite is composed of homogeneous mylonitic grey orthogneiss with strongly deformed mafic xenoliths and high-angle mylonitic foliation. Selected geosites of the geological framework "Mineralization": c) Geosite Collophanites of Itataia: The geosite occur as a collophanite stockwork filling fractures, faults and carbonate breccias in marbles and calc-silicate rocks. The genesis of ore is marked by various mineralizing stage, which ultimately form the larger phosphate-uranium deposit known in South America. (Source: Veríssimo et al. 2016) (Images: César Veríssimo). d) Geosite Skarns of Paraíso: This outcrop constitutes a good exposure of $\mathrm{Fe}-\mathrm{Cu}$ skarns associated to calc-silicate rocks and Neoproterozoic granites. It represents the first occurrence of metallic mineralization identified as product of the SQMA (Source: Parente et al. 2015) (Images: Clóvis V. Parente). Selected geosites of the geological framework "Granitic Rocks": e) Geosite Serra do Barriga Granite: This Cambrian, 522-Ma polyintrusive granitic stock, represents the post-orogenic magmatism at the end of Brasiliano-Pan African Cycle. The stock is formed by rocks ranging in composition from sienogranite to monzogranite. f) Geosite Quixeramobim Granite: This Neoproterozoic, 587 Ma intrusive batholith represents the ending of Brasiliano-Pan-African Cycle being its intrusive processes associated to Senador Pompeu and Quixeramobim shear zones. The batholith is formed by rocks ranging in composition from calc-alkaline granodiorites, diorites, granites and quartz-diorite (Source: Almeida et al. 1999). The area chosen as geosite is a porphyritic grey granite with $15 \mathrm{~cm}$ K-feldspar phenocrysts. Kinematic indicators suggested dextral movement according to regional shear zone can be easily founded. Selected geosites of the geological framework “Geomorphological Units": g) Geosite Inselbergs Field of Quixadá: This geosite represents the most relevant inselbergs field of CCD and one the most known of Brazil. It constitutes a singular landform assemblage resulting from interaction between climate and crystalline rocks. The Galinha Choca is the most famous inselberg, being composed of rich- plagioclase porphyritic granite with mafic enclaves, leucocratic granite portions and quartzfeldspar veins. The inselberg field is characterised by taffonis and marginal collapse of joint blocks. h) Geosite Serra Branca Peak: This 1154-metres peak constitutes CCD's highest point, predominantly composed of K-feldspar granite with small quartz veins associated to SQMA. The geosite represents a residual massif, named Serra das Matas, where highlands with average elevations between 500 and 600 meters can be observed.

igneous petrology, metamorphism, mineral, karst and tectonics (Figure 4a). Metamorphism is the most recurrent interest, clearly due to the geological features of CCD. Geodynamics is the second most recurrent one and includes geosites showing registers of high-pressure and high-temperature zones, mainly regarding oceanic subduction processes. Furthermore, this information may guide future work concerning the use of these geosites, like thematic guides aiming either educational or geotourism purpose.

Regarding the size category, point-type sites were predominant, followed by area, section, viewpoint and complex area (Figure 4b). According to Fuertes-Gutiérrez and Fernández-Martínez (2010), this classification is used to indicate the most vulnerable geosites, being the point- and section-types the most vulnerable, essentially due to their small size. In this inventory, $30.6 \%$ of points or sections geosites were located in road cuttings, a fact that increases their vulnerability.

\section{DISCUSSION}

The first initiatives for geosites conservation in Brazil, such as SIGEP, GEOSSIT Platform, and Geoparks Project stimulated the development of several types of research in Geoconservation. Starting with AD HOC-based methods, these works evolved to the application of well-established, internationally recognised methods, like the Inventory of Geological Heritage of the State of São Paulo (Garcia et al. 2017) and the inventory here presented, among others. The geosites defined in these works are candidates to compound the basis for a future systematic inventory of the Brazilian Geoheritage. Moreover, the experience with these inventories indicates the use of tectonic domains' approach, as pioneered by Mansur (2010a), has 
brought promising results and could be also used as a basis for this national inventory.

In this sense, the geological frameworks presented here represent the most relevant aspects of CCD's geodiversity and can be used for future inventories in the south-west portion of CCD and could serve as a guide in other domains of the Borborema Province with similar geological evolution, as the Médio Coreaú Domain. These frameworks may represent a specific geological event, as Santa Quitéria Magmatic Arc; similar geological features produced by distinct events, such as Mineralisation and Geomorphological Units; or geological features belonging to a specific period in geological time, as Archean and Paleoproterozoic Terranes.

In terms of geological time scale, this inventory comprises geosites representing lithologies from the Neoarchean $(2.88 \mathrm{Ga}$ - Tonalitic Gneiss of Estrema Geosite) to the last Ordovician magmatic pulses (470 Ma - Biotite Sienogranite of Quintas Ring Complex Geosite), later suffering a continuous exhumation and weathering that sculpts the relief until the present. Some geosites represent a geological milestone in the CCD history, like the Garnet-Clinopyroxenite Amphibolite of Juazeiro Farm geosite, mentioned by Santos et al. (2015) as evidence for a continental lithosphere subduction event occurred during the Western Gondwana collage.

Most of the geosites were intensively studied and therefore there are scientific publications about them, resulting in decades of accumulated scientific knowledge and investments of both public and private resources (Figure 5). In this perspective, the inventory can be taken as an extensive survey that gathers information about the most significant research, all assembled in a single database. Therefore, this can facilitate the access to these data by geoscientists either for scientific purposes or communication with the general public, public managers, and funding agencies.
Other geosites correspond to outcrops frequently visited during university field classes or that were subject to academic research and technical reports, contributing to the development of geosciences and training of new professionals (Figure 5). In a study carried out in Europe, Van Loon (2008) brought attention to the threat for the capability of the future professionals in geosciences to manage all kinds of natural resources due to the decrease of field training.

\section{GEOSITES ASSESSMENT IN ACCORDANCE WITH LEGAL PROTECTION AND AWARENESS}

Only $27 \%$ of the inventoried geosites are located in areas with some kind of legal protection (Table III). For instance, only the Inselberg Fields of Quixadá Geosite is located in protected area according to SNUC, designated as Monólitos de Quixadá Natural Monument. Some geosites are protected by National Historic and Artistic Heritage laws due to the occurrence of archaeological features, mainly carving and rock paintings. Geosites classified as Permanent Protection Areas are located surrounding drainages, dams or hilltops.

Most of the geosites $(73 \%)$ are located in places without any legal protection. In this group, geosites located in road cuts constitute the most urgent vulnerable situation. Their vulnerability increases due to the absence of legal protection, especially in cases where enlargement and maintenance of roads, intervention on landslides and illegal graffiti may affect them directly and permanently. For example, the Tonalitic Gneiss of Mombaça is one of the older lithotypes of CCD and in 2016 the main outcrop was partially destroyed due to the enlargement of the CE-060 Highway. An alternative to protect these geosites could be the establishment of partnerships with the administrations responsible for the management of roads or with municipal decrees regulating land use.

Pure application of legal framework without effective actions to monitor compliance with the 

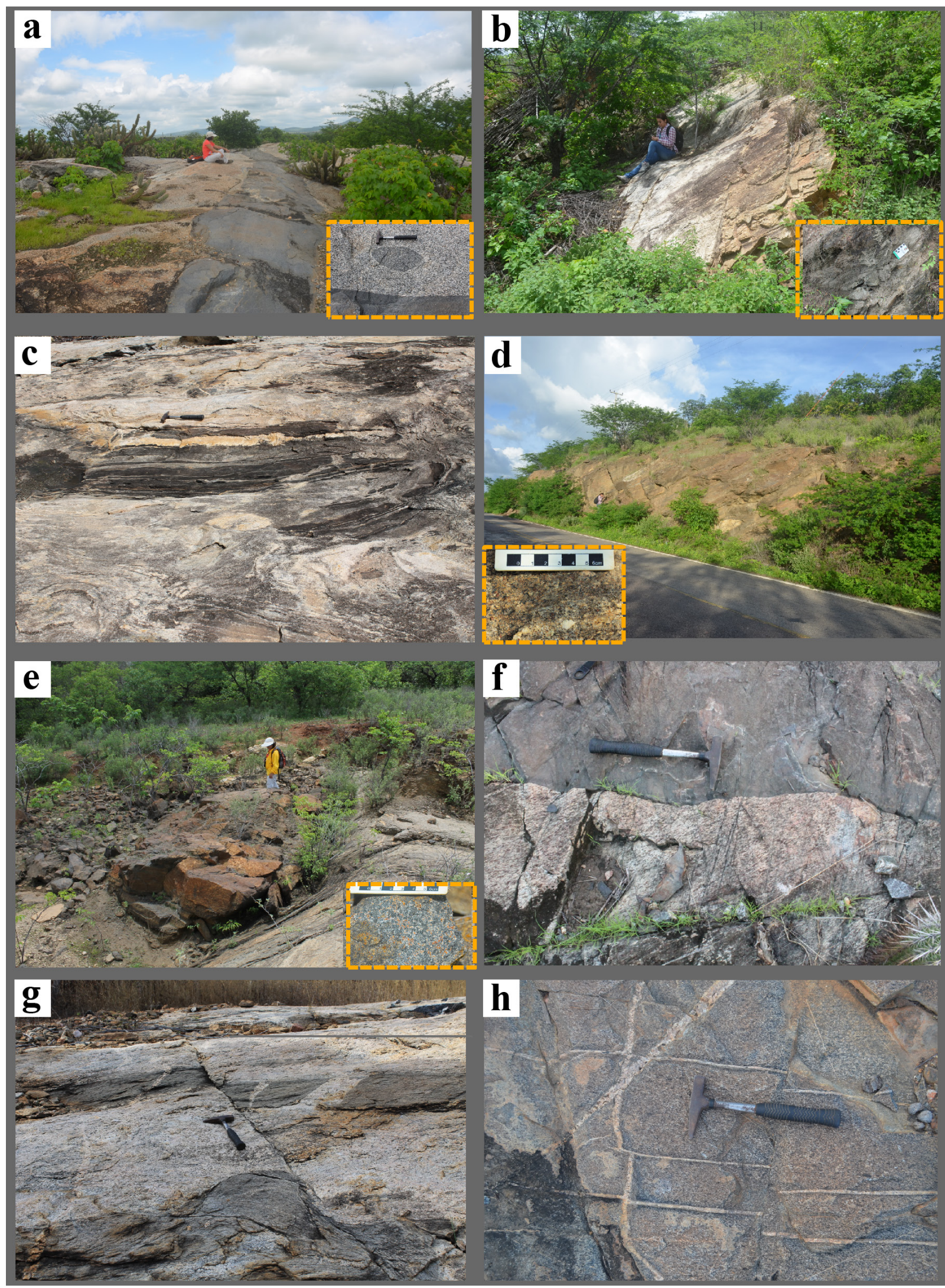
Figure 3 - Selected geosites of the geological framework “Archean and Paleoproterozoic Terranes". a) Geosite Madalena Suite: This outcrop constitutes the best exposure of Paleoproterozoic quartz-dioritic batholith (Madalena Suite) dated about 2.15 and $2.30 \mathrm{Ga}$ and represents a relevant plutonic event affecting Paleoproterozoic rocks assemblage (Source: Costa et al. 2015). The geosite is composed of equigranular hornblende-rich orthogneiss cut by a fine-grained diorite dyke. Mafic enclaves and locally gneissic banding can be observed. b) Geosite Greenstone Sequence of Pedra Branca: This good outcrop represents the greenstone sequence from Troia Massif, one of the most ancient lithotypes of CCD dated about $2.78 \mathrm{Ga}$. It is composed of metarhyolites interlayered with actinolite-rich mafic schists. Selected geosites of the geological framework "Supracrustal Sequences": c) Geosite Metasedimentary Megaxenoliths of Juatama: the best exposure of the relationship between intrusive processes of Neoproterozoic batholiths with the hosting metasedimentary rocks. The geosite is composed of partially-migmatised grey gneiss with metasedimentary xenoliths. These xenoliths were often affected by boudinage, although the primary foliation had been preserved. d) Geosite Kyanite-Sillimanite gneiss of Itatira: This road outcrop is a good exposure that records remarkable retrograded processes related to isothermal decompression during Itatira Nappe evolution, around 630-600 Ma. The site is composed of fine-banded gneiss, with top-to E-NE movement (Source: Garcia et al. 2014). Selected geosites of the geological framework "Granulites and Retroeclogites": e) Geosite Garnet-Amphibolite of Lagoa do Mato: The best exposure of eclogitefacies relics in the CCD represents Neoproterozoic high-pressure metamorphism at the eastern border of SQMA. It is composed of garnet-amphibolite boudins (retrograded eclogites) hosted within aluminous paragnaisses. Plagioclase coronas around garnet can be observed in sample hand. f) Geosite Enderbites of Alto Feliz: This outcrop represents a good exposure of granulite-facies rock in the CCD. It represents records of Neoproterozoic high-grade metamorphism between the western border of SQMA and Brasiliano Lineament and is composed of enderbite crosscut by clinopyroxene-garnet amphibolite dyke. Selected geosites of the geological framework "Santa Quitéria Magmatic Arc": g) Geosite Biotite Diatexite of Santa Quitéria: This geosite is composed of biotite-diatexite related to final phase of SQMA magmatism about $618 \mathrm{Ma}$, and granodiorite boudins with ca. $890 \mathrm{Ma}$ ages, that suggest an older input for SQMA magmatism (Source: Araújo et al. 2014). h) Geosite Quartz-Diorite of Taperuaba: This outcrop constitutes a good exposure of rocks related to SQMA mature arc magmatism at about $648 \mathrm{Ma}$, characterised by hybrid magmatism with influence of neoproterozoic crustal components (Source: Araújo et al. 2014). This site is composed of partially mylonitic quartz-diorite with mafic enclaves cut by felsic veins and fractures.

law, without scientific and popular engagement, does not guarantee adequate conservation for the geosites. As an example, some legally protected geosites present moderate or advanced degradation stages, such as illegal graffiti and garbage, like the Casa de Pedra Cave and Inselberg of Pedra do Cruzeiro geosites. Especially in Brazil, the protection of geoheritage also depends on the recognition of geoconservation as a new area within the Earth Sciences by the geoscience community, as appointed by Lima et al. (2016).

Geoscientists need to take over their social role in spreading their knowledge, so that society could recognise geoheritage as scientific memory, cultural identity and as a basis for sustainable development, making a link to the appropriate legislation for the conservation of geosites (Figure 6). For instance, Spain and Portugal were successful in influencing the legislative system in their countries, including special laws to the protection of geodiversity, thanks to the recognition of geoheritage by society, governments, and academic community (Brilha et al. 2013, Carcavilla et al. 2009). In this regard, the interdisciplinary behaviour of geoconservation may fill the gap between geological research and society. Then, inventories emerge as a fundamental and priority action in this process.

\section{CONCLUSIONS}

In large countries like Brazil, the development of geoheritage inventories using the tectonic domains' approach may be quite adequate. Based on this principle, the inventory of geoheritage of the northern-central part of CCD has resulted in eight geological frameworks and 52 geosites, most of them with a scientific research history and use in university field classes.

The development of this work attends the geological framework methodology; potentially allowing comparison with others inventories in Brazil by using the same method, as well as comparative assessments at an international 

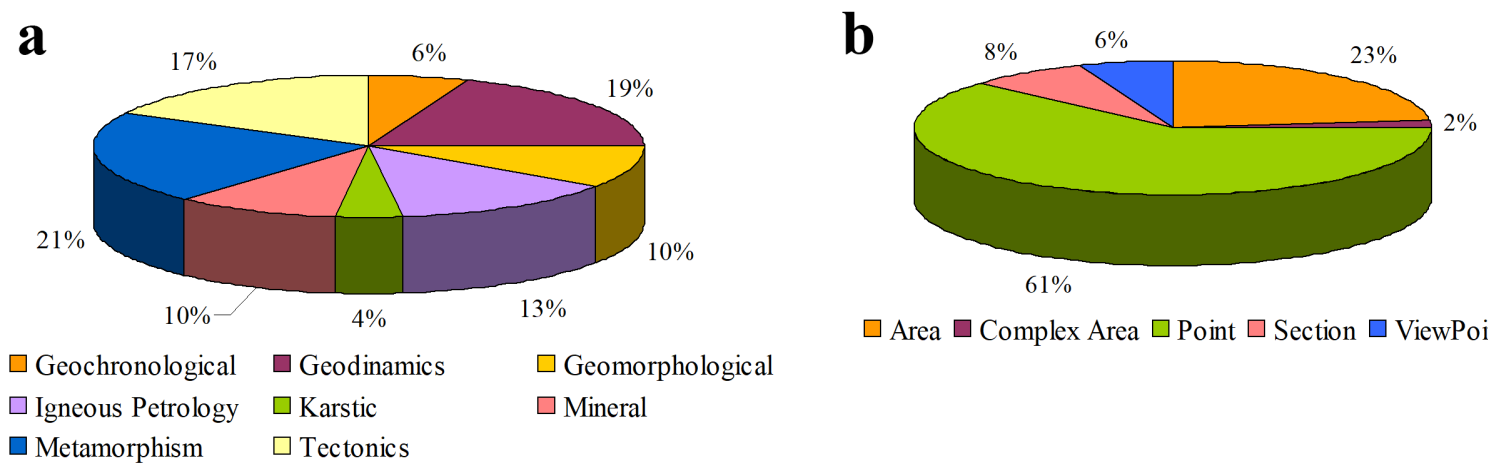

$\square$ Area $\square$ Complex Area $\square$ Point $\square$ Section $\square$ ViewPoint

Figure 4 - a) Distribution of geosites according to main geological interest. b) Distribution of geosites according typological categories of Fuertes-Gutiérrez and Fernández-Martínez (2010).

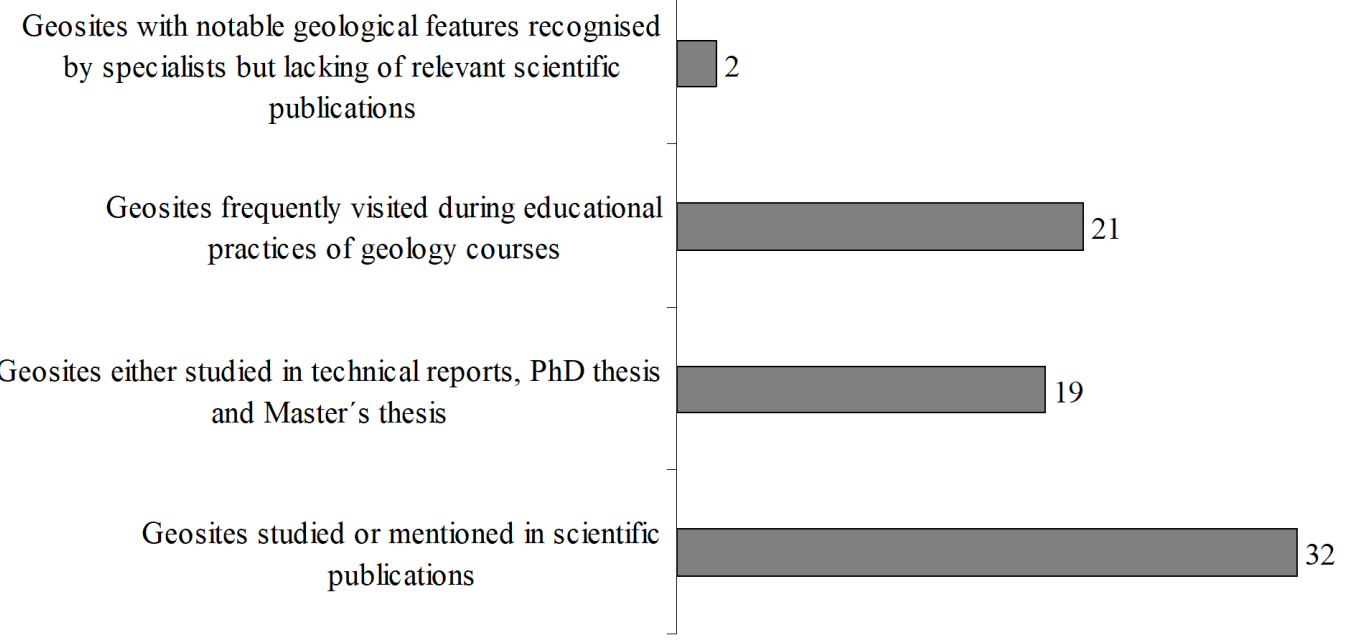

Figure 5 - Frequency of geosites mentioned in each category. The same geosite can be cited in more than one category.

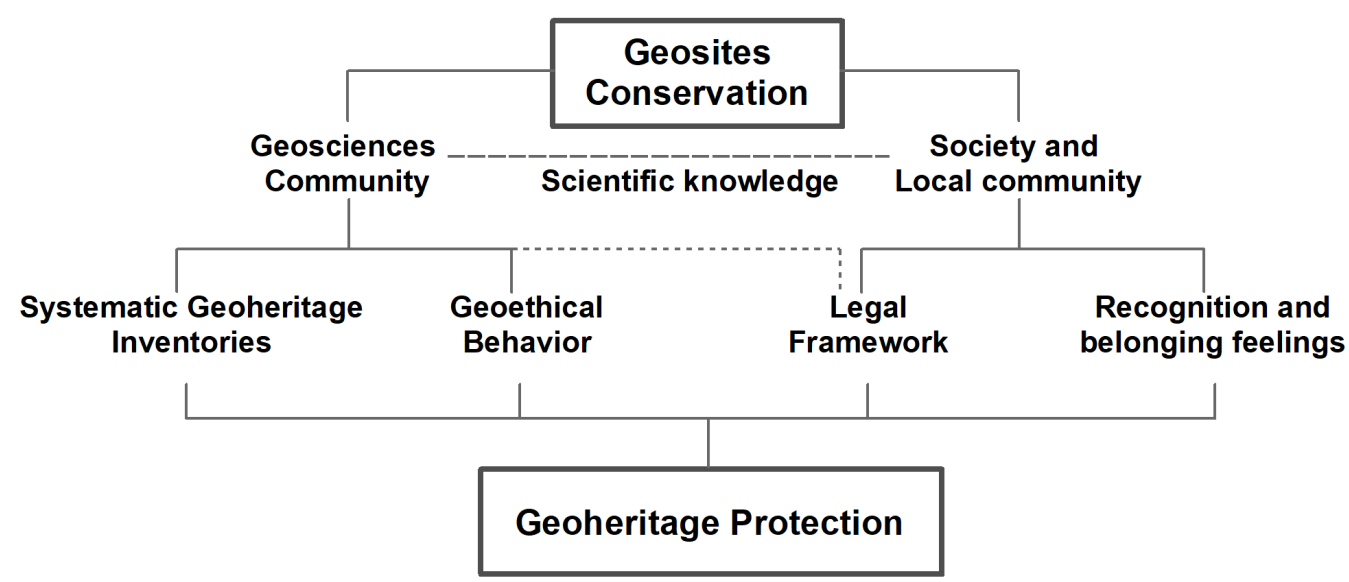

Figure 6 - Conceptual flowchart showing how geosites conservation can be used as a tool to protect geoheritage. Dashed lines indicate indirect influence 
TABLE III

Geosites protected according to Brazilian legal framework.

\begin{tabular}{|c|c|c|}
\hline Legal Framework & Geosite & Modality \\
\hline $\begin{array}{l}\text { Brazilian Law for National Historic and } \\
\text { Artistic Heritage Protection } \\
\text { (Federal Decree-Law n } 25 / 1937 \text { ) }\end{array}$ & $\begin{array}{l}\text { Casa de Pedra Cave } \\
\text { Pajé Range }\end{array}$ & $\begin{array}{l}\text { Archaeological, Ethnographic and } \\
\text { Landscape Heritage Register }\end{array}$ \\
\hline $\begin{array}{c}\text { Brazilian System for Conservation Units } \\
\text { - SNUC } \\
\text { (Federal Law n 9.985/2000) }\end{array}$ & Inselberg Fields of Quixadá & $\begin{array}{l}\text { Natural Monument } \\
\text { (Ceará Decree n 26.805/2002) }\end{array}$ \\
\hline $\begin{array}{c}\text { Brazilian Law for Natural Underground } \\
\text { Cavities Protection } \\
\text { (Decree-Law n 99.556/1990 and } \\
6.640 / 2008 \text { ) } \\
\end{array}$ & $\begin{array}{c}\text { Furna dos Ossos } \\
\text { Casa de Pedra Cave }\end{array}$ & Speleological Heritage \\
\hline $\begin{array}{c}\text { Brazilian Forest Code } \\
\text { (Federal Law n 12.651/2012) }\end{array}$ & $\begin{array}{c}\text { Madalena Suíte } \\
\text { Micaschist of Choró-Limão Dam } \\
\text { Metasedimentary Megaxenoliths of Juatama } \\
\text { Garnet Schist of Quixeramobim } \\
\text { Serra do Barriga Granite } \\
\text { Itatira Nappe } \\
\text { Enderbites of Transbrasiliano Lineament } \\
\text { Serra Branca Peak } \\
\text { Serra do Pajé } \\
\text { Pedra do Frade }\end{array}$ & Permanent Protection Areas \\
\hline Tejuçuoca Municipal Law s/n & Furna dos Ossos & Ecological Park \\
\hline Quixadá Municipal Law n 1903/2003 & Inselberg of Pedra do Cruzeiro & Environmental Protected Zone \\
\hline
\end{tabular}

level. The use of such methodology opens perspectives for new geoheritage inventories in the Borborema Province, and may also contribute to the development of a future Brazilian national systematic inventory, as it was already initiated by the State of São Paulo.

One of the main problems for geoconservation is the absence of specific laws to ensure the protection of geoheritage. The relationship between legal frameworks and vulnerability is a primary indication of which geosites need urgent protection. In this sense, the point and sectiontypes geosites located in road cuts and without legal protection are the most vulnerable. When not accompanied by scientific and social awareness about the relevance of geoheritage, legal protection itself does not ensure geosites conservation. The engagement of the academic community and of the society is undoubtedly necessary to guide the adequate geosites management and thus promote geoheritage protection.

An inventory of geoheritage is not a final task and must constitute a guide to conduct further geoconservation actions. Besides the geoscientific value, this work would serve as a base for the assessment of both tourism and educational potential uses of these geosites. From the combination of these results with socioeconomic and environmental indicators, a pilot area would be chosen to develop a project aiming the sustainable development at this semiarid part of Northeastern Brazil. 
The development of new geological research will allow the reviewing of the presented geological frameworks, and exclusion or inclusion of new geosites, emphasising the dynamic character of this inventory.

\section{ACKNOWLEDGMENTS}

We specially thank all experts that helped us with this inventory: Afonso Almeida, Carlos E.G. de Araújo, César Veríssimo, Christiano Magini, Clóvis Vaz Parente, Felipe G. Costa, Irani C. Mattos, Neivaldo de Castro, Otaciel de Melo, Sebástian G. Chiozza, Ticiano Santos and Stefano Zincone. We are also thankful to Kátia Mansur, Ricardo Fraga Pereira and anonymous reviewers for their valuable contributions. PM is grateful to Coordenação de Aperfeiçoamento de Pessoal de Nível Superior (CAPES) for PhD mobility scholarship PDSE Program/Process n 88881.132168/2016-01.

\section{REFERENCES}

ALMEIDA AR, PARENTE CV AND ARTHAUD MH. 2007. Nota explicativa integrada com Quixeramobim e Boa Viagem: Itatira-SB.24-V-B-V: 1:100.000. Fortaleza: CPRM, $196 \mathrm{p}$

ALMEIDA AR, ULBRICH HGJ AND MCREATH I. 1999. O Batólito Quixadá: petrologia e geoquímica. Rev Geol 12: $29-52$

AMARAL WS AND SANTOS TJS. 2008. Airbone Geophysical and Tectonics of the Ceará Central Domain, Eastern Region of the Santa Quitéria Magmatic Arc, Borborema Province, NE Brazil. Braz J Geophys 26(4): 527-542.

AMARAL WS, SANTOS TJS, ANCELMI MF, FUCK RA, DANTAS EL, MATTEINI M AND MORETO CP. 2015. $1.57 \mathrm{Ga}$ protolith age of the Neoproterozoic Forquilha eclogites, Borborema Province, NE-Brazil, constrained by $\mathrm{U}-\mathrm{Pb}$, Hf and $\mathrm{Nd}$ isotopes. J South Am Earth Sci 58: 210-222.

AMARAL WS, SANTOS TJS AND WERNICK E. 2011. Occurrence and geochemistry of metamafic rocks from the Forquilha Eclogite Zone, central Ceará (NE Brazil): geodynamic implications. Geol J 46: 137-155.

AMARAL WS, SANTOS TJS, WERNICK E, NOGUEIRA NETO JA, DANTAS EL AND MATTEINI M. 2012. Highpressure granulites from Cariré, Borborema Province, NE Brazil: Tectonic setting, metamorphic conditions and U-
$\mathrm{Pb}, \mathrm{Lu}-\mathrm{Hf}$ and Sm-Nd geochronology. Gondwana Res 22: 892-909.

ANCELMI MF, SANTOS TJS, AMARAL WS, FUCK RA, DANTAS EL AND ZINCONE SA. 2015. Provenance of metasedimentary rocks from the Ceará Central Domain of Borborema Province, NE Brazil: implications for the significance of associated retrograded eclogites. J South Am Earth Sci 58: 82-99.

ANCELMI MF, SANTOS TJS, REGINATO RA, AMARAL WS AND MONTEIRO LVS. 2013. Geologia da Faixa Eclogítica de Forquilha, Domínio Ceará Central, noroeste da Província Borborema. Braz J Geol 43(2): 235-252.

ARAÚJO CEG, CORDANI UG, WEINBERG RF, BASEI M AS, ARMSTRONG R AND SATO K. 2014. Tracing neoproterozoic subduction in the Borborema Province (NE-Brazil): Clues from U-Pb geochronology and $\mathrm{Sr}-\mathrm{Nd}-$ Hf-O isotopes on granitoids and migmatites. Lithos 202203: $167-189$.

ARAÚJO CEG, COSTA FG, PINÉO TRG, CAVALCANTE JC AND MOURA CAV. 2012. Geochemistry and $207 \mathrm{~Pb} / 206 \mathrm{~Pb}$ zircon ages of granitoids from the southern portion of the Tamboril-Santa Quitéria granitic-migmatitic complex, Ceará Central Domain, Borborema Province (NE Brazil). J South Am Earth Sci 33(1): 21-33.

ARTHAUD MH, CABY R, FUCK RA, DANTAS EL AND PARENTE CV. 2008. Geology of the northern Borborema Province, NE Brazil and its correlation with Nigeria, NW Africa. 2008. Geol Soc Spec Publ 294(1): 49-67.

ARTHAUD MH ET AL. 1993. Evolução termo - dinâmica da Sequência Metassedimentar de Quixeramobim (CE): Suas consequências quanto ao funcionamento das transcorrências dúcteis do Ceará Central. Rev Geol 6(1): 47-56.

BORBA AW, SOUZA LF, MIZUSAKI AMP, ALMEIDA DPM AND STUMPF PP. 2013. Inventário e avaliação quantitativa de geossítios: exemplo de aplicação ao patrimônio geológico do município de Caçapava do Sul (RS, Brasil). Pesq Geoc 40(3): 275-294.

BRAZIL. 1937. Decreto-Lei 25, de 30 de novembro de 1937. Organiza a proteção do patrimônio histórico e artístico nacional. Disponível em: <http://www.planalto.gov.br/ ccivil 03/decreto-lei/De10025.htm>. Acesso em: 09 de maio de 2016.

BRAZIL. 1990. Decreto-Lei 99556, de 1 de outubro de 1990. Dispõe sobre a proteção das cavidades naturais subterrâneas existentes no território nacional, e dá outras providências. Disponível em: $<$ http://www.planalto.gov.br/ ccivil_03/decreto/1990-1994/d99556.htm>. Acesso em: 10 de junho de 2016.

BRAZIL. 2000. Lei Federal 9985, de 18 de julho de 2000. Institui o Sistema Nacional de Unidades de Conservação da Natureza e dá outras providências. Disponível em: 
$<$ http://www.planalto.gov.br/ccivil 03/leis/L9985.htm>. Acesso em: 09 de maio de 2016.

BRAZIL. 2008. Decreto-Lei 6640, de 7 de novembro de 2008. Dá nova redação aos arts. $1^{\circ}, 2^{\circ}, 3^{\circ}, 4$ e 5 e acrescenta os arts. 5-A e 5-B ao Decreto $\mathrm{n}$ 99.556, de 1 de outubro de 1990, que dispõe sobre a proteção das cavidades naturais subterrâneas existentes no território nacional. Disponível em: <http://www.planalto.gov.br/ccivil_03/_ ato2007-2010/2008/decreto/d6640.htm>. Acesso em: 10 de junho de 2016.

BRAZIL. 2012. Lei Federal 12651, de 25 de maio de 2012. Dispõe sobre a proteção da vegetação nativa e dá outras providências. Disponível em: <http://www.planalto. gov.br/ccivil_03/_ato2011-2014/2012/lei/112651.htm>. Acesso em: 09 de maio de 2016.

BRILHA J. 2016. Inventory and Quantitative assessment of geosites and geodiversity sites: a review. Geoheritage 8(2): 119-134.

BRILHA J ET AL. 2005. Definition of the Portuguese Frameworks with international relevance as an input for the European geological heritage characterization. Episodes 28(3): 177-186.

BRILHA J ET AL. 2013. Geossítios de Relevância Nacional e Internacional em Portugal Continental. In: Magalhães MR (Ed), Estrutura Ecológica Nacional: Uma proposta delimitação e regulamentação. Lisboa: ISAPress, 2013. Cap. 9, p. 169-175.

BRITO NEVES BB, CAMPOS NETO M AND FUCK RA. 1999. From Rodinia to Western Gondwana: an approach to the Brasiliano-Pan African Cycle and orogenic collage. Episodes 22(3): 155-166.

BUTLER R. 2015. Destructive sampling ethics. Commentary. Nat Geosci 8(1): 817-818.

CABY R AND ARTHAUD MH. 1986. Major Precambrian nappes of the Brazilian belt, Ceara, northeast Brazil. Geol 14: 871-874.

CARCAVILLA LU. 2012. Geoconservación. Instituto Geológico y Minero de España, Madrid, 126p.

CARCAVILLA LU, DURÁN JJ, GARCÍA-CORTÉS A AND LÓPEZ-MARTINÉZ J. 2009. Geological heritage and geoconservation in Spain: past, present, and future. Geoheritage 1: 75-91.

CASTRO NA, ARAÚJO CEG, BASEI MAS, OSAKO LS, NUTMAN AA AND LIU D. 2012. Ordovician A-type granitoid magmatism on the Ceará Central Domain, Borborema Province, NE-Brazil. J South Am Earth Sci $36: 18-31$.

CAVALCANTE JC, VASCONCELOS AM, MEDEIROS MF, PAIVA IP, GOMES FEM, CAVALCANTE SN, CAVALCANTE JE, MELO ACR, DUARTE NETO VC AND BENEVIDES HC. 2003. Mapa geológico do Estado do Ceará, escala 1:500.000. Fortaleza, Secretaria das Minas e Energia, CPRM.
CEARÁ. 2002. Decreto 26805, de 25 de outubro de 2002. Decreta a Unidade de Conservação de Proteção Integral do tipo Monumento Natural os campos de inselbergs situados no Município de Quixadá. Disponível em: $<\mathrm{http}: / /$ antigo.semace.ce.gov.br/biblioteca/legislacao/conteudo legislacao .asp?cd=170>. Acesso em: 10 de junho de 2016. COSTA FG, PALHETA ESM, RODRIGUES JB, GOMES IP AND VASCONCELOS AM. 2015. Geochemistry and U$\mathrm{Pb}$ zircon ages of plutonic rocks from the Algodões granitegreenstone terrane, Tróia Massif, northern Borborema Province, Brazil: Implications for Paleoproterozoic subduction-accretion processes. J South Am Earth Sci 59: 45-68.

DRUGET E, PASSHIER CW, PENNACHIONI G AND CARRERAS J. 2013. Geoethical education: A critical issue for geoconservation. Episodes 36(1): 11-18.

FETTER AH, SANTOS TJS, VAN SCHMUS WR, HACKSPACHER PC, BRITO NEVES BB, ARTHAUD MH, NOGUEIRA NETO JA AND WERNICK E. 2003. Evidence for neoproterozoic continental arc magmatism in the Santa Quiteria Batholith of Ceara State, NW Borborema Province, NE Brazil: Implications for the assembly of West Gondwana. Gondwana Res 6(2): 265-273.

FETTER AH, VAN SCHMUS WR, SANTOS TJS, NOGUEIRA NETO JA AND ARTHAUD MH. 2000. $\mathrm{U}-\mathrm{Pb}$ and $\mathrm{Sm}-\mathrm{Nd}$ geochronological constraints on the crustal evolution and basement architecture of Ceará State, NW Borborema Province, Ne Brazil: Implications for the existence of the paleoproterozoic supercontinent "Atlantica". Braz J Geol 30: 102-106.

FUERTES-GUTIÉRREZ I AND FERNÁNDEZ-MARTÍNEZ E. 2010. Geosites inventory in the Leon Province (Northwestern Spain): A tool to introduce geoheritage into regional environmental management. Geoheritage 2(1-2): 57-75.

GARCIA MGM AND ARTHAUD MH. 2004. Caracterização de trajetórias P-T em nappes brasilianas: região de Boa Viagem/Madalena - Ceará Central. Rev Geol 17(2): 173191.

GARCIA MGM, BRILHA J AND LIMA FF ET AL. 2017. The Inventory of Geological Heritage of the State of São Paulo, Brazil: Methodological Basis, Results and Perspectives. Geoheritage 1: 1-20.

GARCIA MGM, SANTOS TJS AND AMARAL WS. 2014. Provenance and tectonic setting of neoproterozoic supracrustal rocks from the Ceará Central Domain, Borborema Province (NE Brazil): constraints from geochemistry and detrital zircon ages. Int Geol Rev 56(4): 481-500.

HENRIQUES MH, REIS RP, BRILHA J AND MOTA T. 2011. Geoconservation as an emerging geoscience. Geoheritage 3(2): 17-128. 
IAPG. 2012. What is Geoethics? International Association for Promoting Geoethics (IAPG). Available: http://www. geoethics.org/geoethics. Last accessed January 2017.

IRWIN WP. 1972. Terranes of the western Paleozoic and Triassic belt in the southern Klamath Mountains, California. Geol Surv Res Chap C 1: 103-111.

KEAREY F AND VINE FJ. 1998. Global Tectonics. Oxford, Blackwell Science, $2^{\text {nd }}$ ed., 333 p.

LIMA FF, BRILHA J AND SALAMUNI E. 2010. Inventorying geological heritage in large territories: A methodological proposal applied to Brazil. Geoheritage 2(3-4): 91-99.

LIMA FF, SCHOBBENHAUS C AND NASCIMENTO MAL. 2016. Património geológico y su conservación en América Latina: Situación y perspectivas nacionales: Brasil. In: Prieto J and Palácio L (Eds), Geografía para el siglo XXI: Libros de investigación, 18, México, Universidad Nacional Autónoma de México, p. 55-79.

LIMA LC, MORAIS JO AND SOUZA MJN. 2000. Compartimentação Territorial e Gestão Regional do Ceará. Fortaleza, FUNECE, 268 p.

MAIA RP, BEZERRA FHR AND SALES VC. 2010. Geomorfologia do Nordeste: Concepções clássicas e atuais acerca das superfícies de aplainamento nordestinas. Rev Geogr 1(1): 6-19.

MAIA RP, NASCIMENTO MAL, BEZERRA FHR, CASTRO HS, MEIRELES AJA AND ROTHIS LM. 2015. Geomorfologia do campo de Inselbergues de Quixadá, nordeste do Brasil. Ver Bras Geomorfo 16(2): 239-253.

MANSUR KL. 2010a. Diretrizes para a Geoconservação do Patrimônio Geológico do Estado do Rio de Janeiro: o caso do Domínio Tectônico Cabo Frio. Tese de Doutorado, PósGraduação em Geologia, UFRJ, Rio de Janeiro, 214 p.

MANSUR KL. 2010b. Ordenamento territorial e geoconservação: análise das normas legais aplicáveis no Brasil e um caso de estudo no estado do Rio de Janeiro. Geociências 29(2): 237-249.

MANSUR KL, PONCIANO LCMO AND CASTRO ARSF. 2017. Contributions to a Brazilian Code of Conduct for Fieldwork in Geology: an approach based on Geoconservation and Geoethics. An Acad Bras Cienc 89: 431-444.

MARTINS G AND OLIVEIRA EP. 2004. Arcabouço LitoEstrutural da Suíte Metamórfica Algodões-Choró, Domínio Ceará Central da Província Borborema. Rev Geol 17(1): 38-51.

NEVES SP. 1991. A Zona de Cisalhamento de Tauá, Ceará: Sentido, estimativa do deslocamento, evolução estrutural e granitogênese associada. Braz J Geol 21(2): 161-173.

PARENTE CV, VERÍSSIMO CUV, BOTELHO NF AND SANTOS TJS. 2015. Depósitos de escarnitos mineralizados em ferro e cobre do Arco Magmático de Santa Quitéria,
Ceará, Província Borborema do nordeste do Brasil. Braz J Geol 45(3): 359-382.

PEULVAST JP AND SALES VC. 2002. Aplainamento e Geodinâmica: Revisitando um problema clássico em geomorfologia. Mercator 1(1): 113-150.

ROCHA AJD, LIMA E AND SCHOBBENHAUS C. 2016. Aplicativo GEOSSIT - nova versão. In: Congresso Brasileiro de Geologia, 48, 2016, Porto Alegre. Anais da Sociedade Brasileira de Geologia, São Paulo, p. 6389.

SALES VC AND PEULVAST JP. 2007. Evolução morfoestrutural do revelo da margem continental do estado do Ceará, nordeste do Brasil. Caminhos Geogr 7(20): 1-21.

SANTOS TJS, AMARAL WS, ANCELMI MF, PITARELLO MZ, FUCK RAAND DANTAS EL. 2015. U-Pb age of the coesite-bearing eclogite from NW Borborema Province, NE Brazil: Implications for western Gondwana assembly. Gondwana Res 28(3): 1183-1196.

SANTOS TJS, GARCIA MGM, AMARAL WS, CABY R, WERNICK E, ARTHAUD MH, DANTAS EL AND SANTOSH M. 2009. Relics of eclogite facies assemblages in the Ceará Central Domain, NW Borborema Province, NE Brazil: Implications for the assembly of West Gondwana. Gondwana Res 15(3-4): 454-470.

SCHOBBENHAUS C, ROCHA AJD, WINGE M AND LIMA E. 2015. Inventário de Sítios do Patrimônio Geológico do Brasil. In: Simpósio Brasileiro de Patrimônio Geológico, 3, 2015, Lençóis. Anais do Simpósio Brasileiro de Patrimônio Geológico, Lençóis, 468-471 p.

THOMAS BA AND WARREN LM. 2008. Geological conservation in the nineteenth and early twentieth centuries. In. Burek CV and Prosser CD (Eds), The History of Geoconservation. Geol Soc Spec Publ 300: 17-30.

VAN LOON AJ. 2008. Geological education of the future. Earth-Sciences Rev 86(1-4): 247-254.

VERÍSSIMO CUV, SANTOS RV, PARENTE CV, OLIVEIRA CG, CAVALCANTI GAD AND NOGUEIRA NETO JA. 2016. The Itataia phosphate-uranium deposit (Ceará, Brazil): new petrographic, geochemistry and isotope studies. J South Am Earth Sci 70: 115-144.

VERÍSSIMO CUV, MAGINI C AND PARENTE CV. 2009. Petrografia e litoquímica das Formações Ferríferas Bandadas de Quixeramobim-Boa Viagem, Ceará, Brasil. Geociências 28(1): 43-52.

WIMBLEDON W. 1996. Geosites: a new conservation initiative. Episodes 19(3): 87-88.

WIMBLEDON W, ANDERSEN S, CLEAL CJ AND COWIE JW. 1999. Geological World Heritage: GEOSITES - A global comparative site inventory to enable prioritisation for conservation. Mem Descrittive della Carta Geol D'Italia 54: 45-60. 